\title{
Chemistry of Diazafulvenium Methides in the Synthesis of Functionalized Pyrazoles
}

\author{
Teresa M. V. D. Pinho e Melo, ${ }^{*},{ }^{\dagger}$ Cláudio M. Nunes, ${ }^{\dagger}$ Maria I. L. Soares,${ }^{\dagger}$ José A. Paixão,, \\ Ana Matos Beja, $\stackrel{\ddagger}{\ddagger}$ and Manuela Ramos Silva \\ Department of Chemistry, University of Coimbra, 3004-535 Coimbra, Portugal, and Department of \\ Physics, University of Coimbra, 3004-516 Coimbra, Portugal \\ tmelo@ci.uc.pt
}

Received February 7, 2007

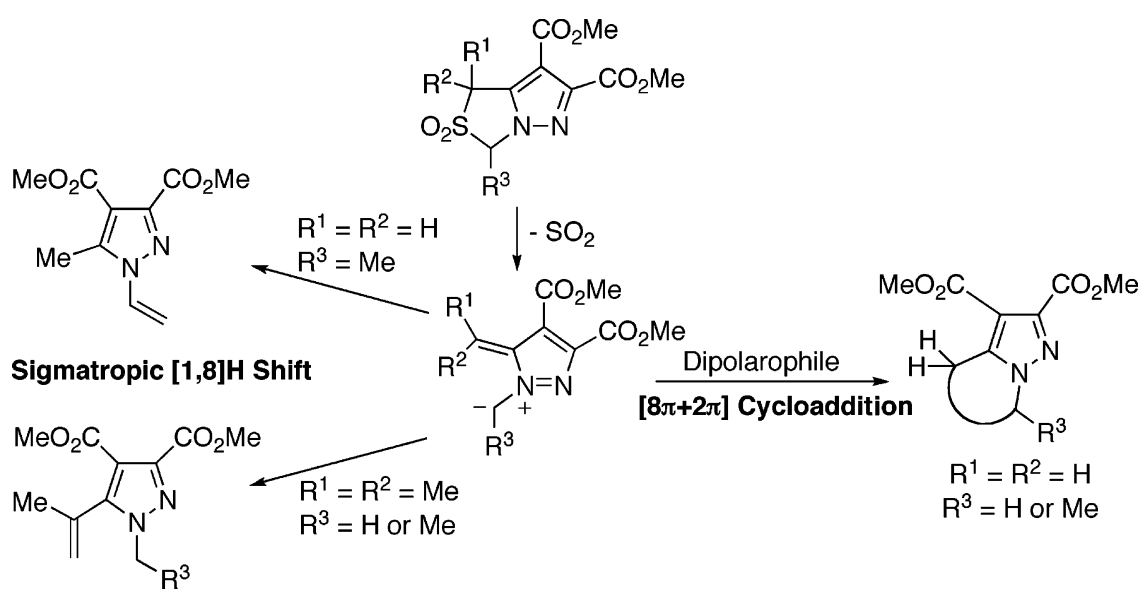

The chemistry of diazafulvenium methides generated by the thermal extrusion of sulfur dioxide from 2,2-dioxo- $1 H, 3 H$-pyrazolo[1,5-c] [1,3]thiazoles is described. The diazafulvenium methides unsubstituted at C-7 participate in $[8 \pi+2 \pi]$ cycloadditions giving pyrazolo-annulated heterocycles resulting from the addition across the 1,7-position. 1-Methyl-diazafulvenium methides and 7,7-dimethyl-diazafulvenium methides undergo intramolecular sigmatropic $[1,8] \mathrm{H}$ shifts giving vinyl- $1 H$-pyrazoles.

\section{Introduction}

The study of pericyclic reactions of extended dipoles (with more than $4 \pi$ electrons) is one of our current research interests. ${ }^{1-4}$ Storr and co-workers have shown that 2,2-dioxo$1 H, 3 H$-pyrrolo[1,2-c][1,3]thiazoles and 2,2-dioxo- $1 H, 3 H$-pyrazolo[1,5-c][1,3]thiazoles are masked aza- and diazafulvenium methides (1 and 2). These $8 \pi$ 1,7-dipoles can be considered

\footnotetext{
$\dagger$ Department of Chemistry.

* Department of Physics.

(1) (a) Pinho e Melo, T. M. V. D.; Soares, M. I. L.; Rocha Gonsalves, A. M. d'A.; McNab, H. Tetrahedron Lett. 2004, 45, 3889-3893. (b) Pinho e Melo, T. M. V. D.; Soares, Maria I. L.; Rocha Gonsalves, A. M. d'A.; Paixão, J. A.; Matos Beja, A.; Ramos Silva, M. J. Org. Chem. 2005, 70, 6629-6638.

(2) Pinho e Melo, T. M. V. D.; Soares, M. I. L.; Nunes, C. M. Tetrahedron 2007, 63, 1833-1841.

(3) Pinho e Melo, T. M. V. D.; Soares, M. I. L.; Rocha Gonsalves, A. M. d'A. Tetrahedron Lett. 2006, 47, 791-794.
}

(4) Pinho e Melo, T. M. V. D. Eur. J. Org. Chem. 2006, 2873-2888. "higher-order" azomethine ylides and azomethine imines, respectively. In fact, the authors described the thermal extrusion of sulfur dioxide from 2,2-dioxo- $1 H, 3 H$-pyrrolo[1,2-c][1,3]thiazoles under flash vacuum pyrolysis (FVP) to give transient 1-azafulvenium methide systems (1) that can be trapped in pericyclic reactions. The dipolar systems 1a-1c undergo sigmatropic $[1,8] \mathrm{H}$ shifts giving vinylpyrroles, and the acyl derivatives $1 \mathbf{d}$ electrocyclize to give pyrrolo[1,2-c][1,3] oxazines. $^{5}$ On the other hand, the $\mathrm{SO}_{2}$ extrusion of the studied 2,2-dioxo$1 H, 3 H$-pyrazolo[1,5-c][1,3]thiazole led to 1,2-diazafulvenium methide 2 , which could be intercepted in $[8 \pi+2 \pi]$ cycloaddition with silylated acetylenes giving adducts resulting from the addition across the 1,7-position (Scheme 1). ${ }^{5}$

(5) (a) Sutcliffe, O. B.; Storr, R. C.; Gilchrist, T. L.; Rafferty, P.; Crew, A. P. A. Chem. Commun. 2000, 675-676. (b) Sutcliffe, O. B.; Storr, R. C.; Gilchrist, T. L.; Rafferty, P. J. Chem. Soc., Perkin Trans. 1 2001, 17951806.

10.1021/jo070265x CCC: $\$ 37.00$ @ 2007 American Chemical Society Published on Web 05/10/2007 


\section{SCHEME 1}

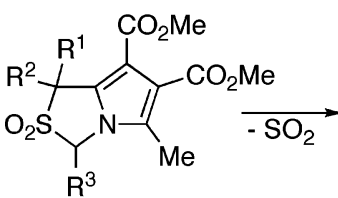<smiles></smiles>

1a $\mathrm{R}^{1}=\mathrm{R}^{2}=\mathrm{H} ; \mathrm{R}^{3}=\mathrm{CH}_{3}$

1b $\mathrm{R}^{1}=\mathrm{H} ; \mathrm{R}^{2}=\mathrm{CH}_{3} ; \mathrm{R}^{3}=\mathrm{H}$

1c $\mathrm{R}^{1}=\mathrm{R}^{2}=\mathrm{CH}_{3} ; \mathrm{R}^{3}=\mathrm{H}$

1d $\mathrm{R}^{1}=\mathrm{H} ; \mathrm{R}^{2}=\mathrm{COR} ; \mathrm{R}^{3}=\mathrm{H}$<smiles></smiles>

\section{SCHEME 2}
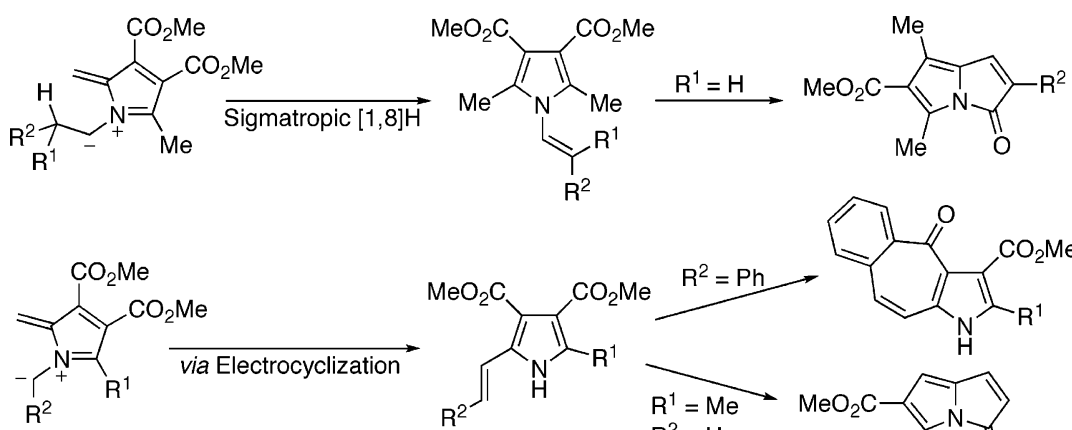

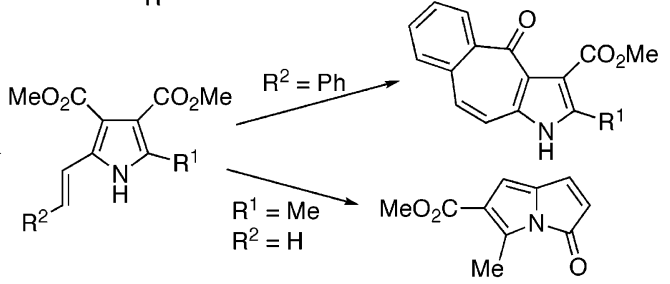

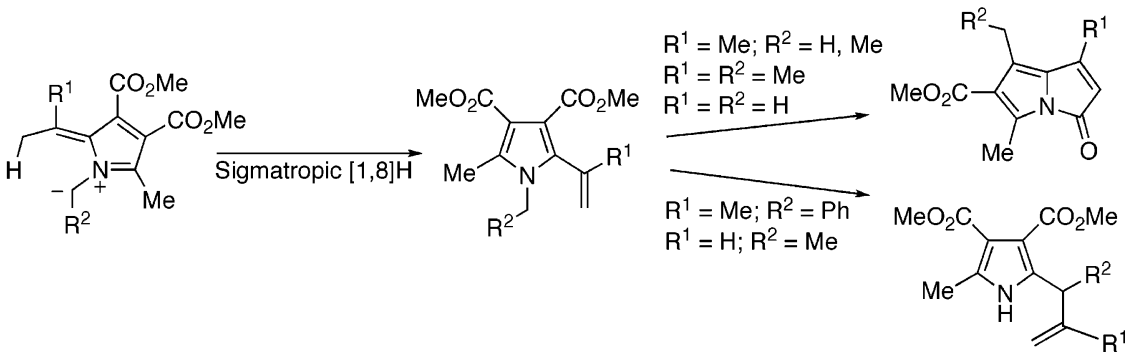

Our own contribution allowed for the definition of a reactivity pattern of azafulvenium methides (Scheme 2). ${ }^{1,2}$ The intramolecular trapping of the transient $8 \pi$ 1,7-dipoles derived from 1-unsubstitued-2,2-dioxo- $1 H, 3 H$-pyrrolo[1,2-c][1,3]thiazoles in pericyclic reactions, namely, sigmatropic $[1,8] \mathrm{H}$ shifts and 1,7electrocyclization, affords $N$-vinylpyrroles and $C$-vinylpyrroles, which under flash vacuum pyrolysis conditions are converted into 5-oxo-5 $\mathrm{H}$-pyrrolizines or 4-oxo-1,4-dihydro-1-aza-benzo[f]azulenes. 7-Methyl- and 7,7-dimethyl-azafulvenium methides undergo sigmatropic $[1,8] \mathrm{H}$ shifts to give $C$-vinylpyrroles even in cases where an alternative pericyclic reaction could in principle occur. Azafulvenium methides generated from C-3 unsubstituted 1-methyl-2,2-dioxo- $1 H, 3 H$-pyrrolo[1,2-c][1,3]thiazole can only undergo the same type of $[1,8] \mathrm{H}$ shift to the corresponding $C$-vinylpyrrole. However, from the reaction of the 1,3-dimethyl-2,2-dioxo- $1 H, 3 H$-pyrrolo[1,2-c][1,3]thiazole derivative the corresponding azafulvenium methide undergoes the two possible sigmatropic $[1,8] \mathrm{H}$ shifts. Rearrangements of these $\mathrm{C}$-vinylpyrroles afford 5-oxo-5 $\mathrm{H}$-pyrrolizines or functionalized $C$-allyl- $1 H$-pyrroles.

The chemistry of 1,2-diazafulvenium methides has also attracted our attention, and our preliminary results have been described. ${ }^{3}$ In this paper, we describe full details of an extensive study on the generation and reactivity of 1,2-diazafulvenium methides.

\section{Results and Discussion}

We prepared the 2,2-dioxo- $1 H, 3 H$-pyrazolo[1,5-c][1,3]thiazole $3^{5,6}$ and observed that it undergoes $\mathrm{SO}_{2}$ extrusion in refluxing 1,2,4-trichlorobenzene to give 1,2-diazafulvenium methide 4, which could be trapped by reacting with bis(trimethylsilyl)acetylene, confirming the result reported by Storr et al. ${ }^{5}$ In our hands, the dimethyl 5,6-bis(trimethylsilyl)-4,7-dihydropyrazolo[1,5-a]pyridine-2,3-dicarboxylate 5 was obtained in $54 \%$ yield together with the formation of the aromatized derivative $\mathbf{6}$ in $7 \%$ yield (Table 1). However, the dipolar system 4 also participates in the cycloaddition with electron-deficient dipolarophiles. Diazafulvenium methide 4 reacts with DMAD to give a mixture of dihydropyrazolo[1,5- $a$ ]pyridines (8 and 9) in $45 \%$ yield and pyrazolo[1,5- $a$ ]pyridine 7 in $10 \%$ yield. The mixture of 8 and 9 can be converted into 7 in $44 \%$ yield by treatment with DDQ. The $[8 \pi+2 \pi]$ cycloaddition of diazafulvenium methide 4 with methyl propiolate affords regioisomers $10(28 \%)$ and $11(33 \%)$. The thermolysis of 2,2-dioxo- $1 H, 3 H$-pyrazolo[1,5-c][1,3]thiazole 3 in refluxing 1,2,4-trichlorobenzene for 7 $\mathrm{h}$ in the presence of $\mathrm{N}$-phenylmaleimide gave hexahydro- $5 \mathrm{H}$ pyrrolo[ $\left[3^{\prime}, 4^{\prime}: 5,6\right]$ pyrazolo[1,5-a]pyridine $\mathbf{1 2}$ in $87 \%$ yield. This cycloadduct could be obtained in $98 \%$ yield by increasing the reaction time to $11 \mathrm{~h}$. The dipole 4 can also be trapped by

(6) Sutcliffe, O. B.; Storr, R. C.; Gilchrist, T. L.; Rafferty, P. Tetrahedron 2000, 56, 10011-10021. 
TABLE 1. Solution Pyrolysis of 2,2-Dioxo-1H,3H-pyrazolo[1,5-c][1,3]thiazole 3 in the Presence of Dipolarophiles

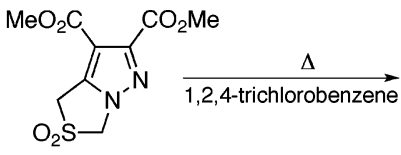

3

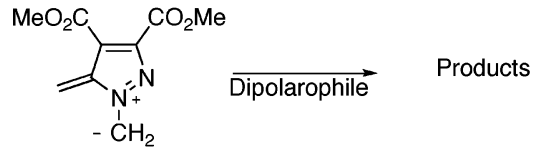

4

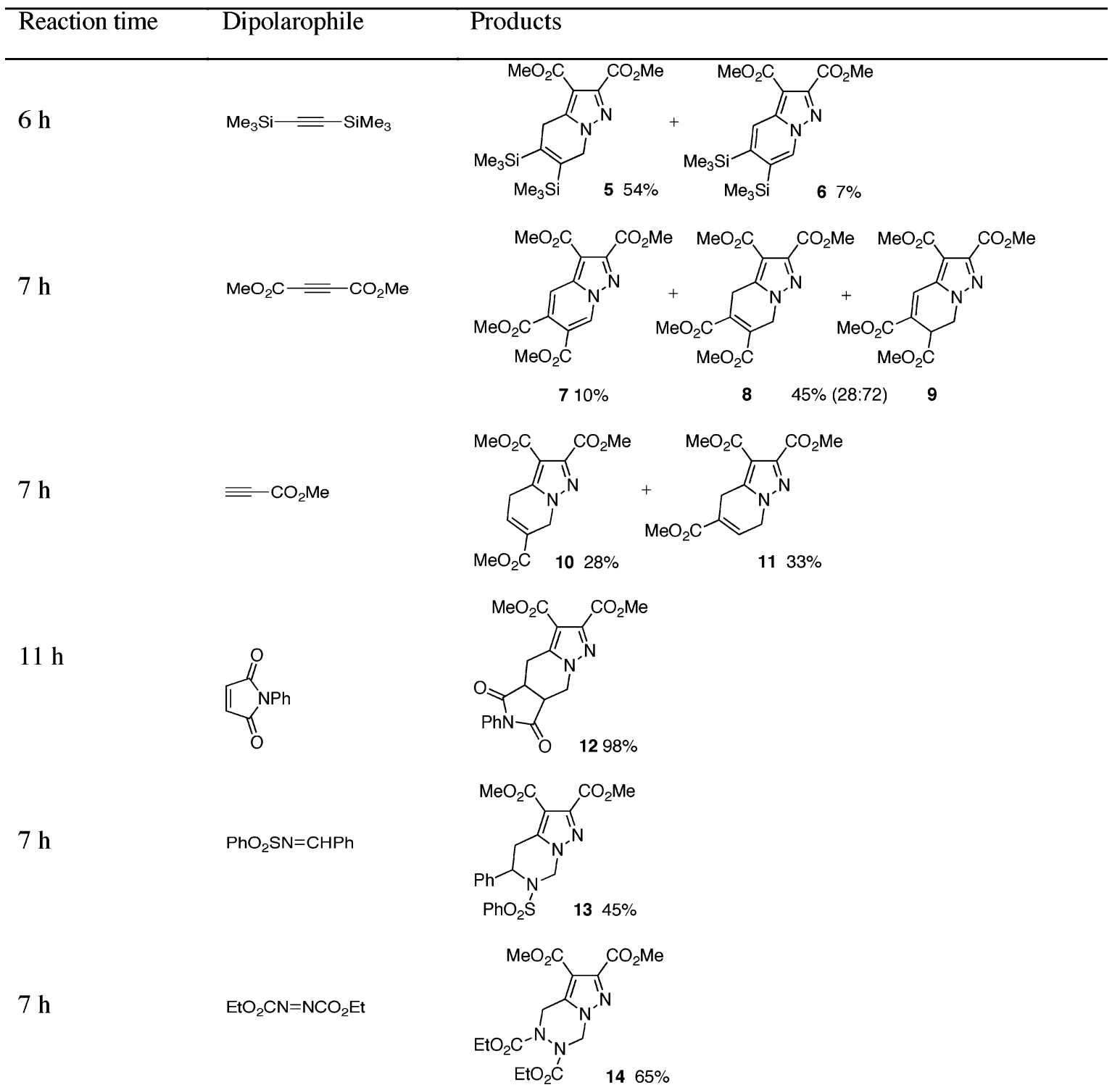

$[8 \pi+2 \pi]$ cycloaddition with heterodipolarophiles. In fact, the reaction with $N$-benzylidenebenzenesulfonamide ${ }^{7}$ gives the corresponding cycloadduct $\mathbf{1 3}$ in $45 \%$ yield as the only regioisomer. On the other hand, pyrazolo[ $[1,5-d][1,2,4]$ triazine 14 could be obtained in $65 \%$ yield from the cycloaddition of 1,2-diazafulvenium methide $\mathbf{4}$ with diethyl diazene-1,2-dicarboxylate (Table 1). These results contradict the previously described experimental observation where cycloaddition of 1,2diazafulvenium methide $\mathbf{4}$ could only be observed with silylated acetylenes and attempts to carry out the reaction with electrondeficient dipolarophiles were not successful. ${ }^{5}$ However, the reactivity of 1,7-dipole 4 toward $[8 \pi+2 \pi]$ cycloaddition hereby

(7) Vishwakarma, L. C.; Stringer, O. D.; Davis, F. A. Organic Syntheses; Wiley: New York, 1993; Collect. Vol. VIII, pp 546-550. described, characterized by the participation in the reaction with both electron-rich and electron-deficient dipolarophiles, is in agreement with the reported MO calculations. ${ }^{5}$

The work was extended to diazafulvenium methide systems generated from 3-methyl-, 1,1-dimethyl-, and 1,1,3-trimethyl2,2-dioxo- $1 H, 3 H$-pyrazolo[1,5-c][1,3]thiazoles 19. The 3methyl-2,2-dioxo- $1 H, 3 H$-pyrazolo[1,5-c][1,3]thiazole $19 \mathbf{a}^{3}$ was prepared from thiazolidine 15a as outlined in Scheme 3. The sydnone 17a is a stable mesoionic species, which can be isolated and undergoes 1,3-dipolar cycloaddition with DMAD to give 3-methyl-1H,3H-pyrazolo[1,5-c][1,3]thiazole 18a in 60\% yield. $1 H, 3 H$-Pyrazolo[1,5-c][1,3]thiazoles $\mathbf{1 8 b}$ and $\mathbf{1 8 c}$ were obtained using a similar synthetic strategy. Thiazolidines $\mathbf{1 5 b}$ and $\mathbf{1 5 c}$ were prepared from the condensation of DL-penicillamine with 


\section{SCHEME 3}
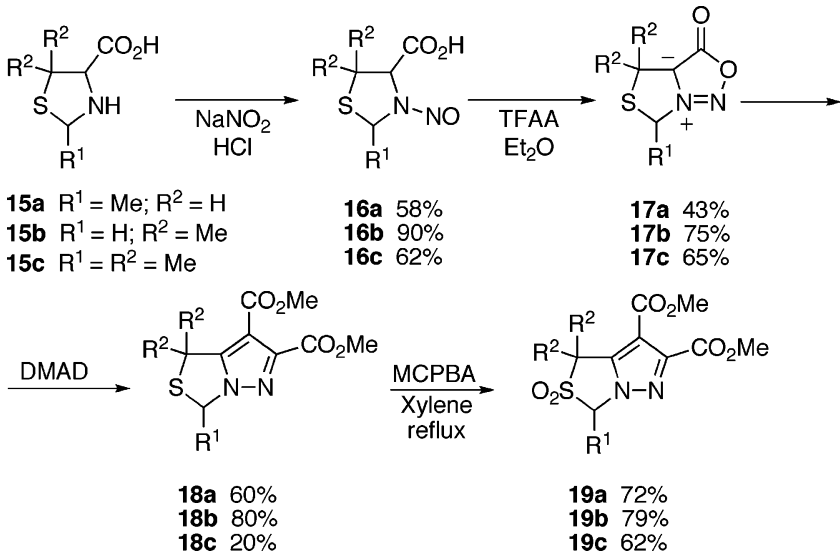

formaldehyde and acetaldehyde, respectively, and converted into the corresponding sydnone via nitrosation followed by treatment with TFAA. Sydnones $\mathbf{1 7 b}$ and $\mathbf{1 7 c}$ are also stable and could be isolated and fully characterized. The reaction of $\mathbf{1 7} \mathbf{b}$ with DMAD gave the expected $1 H, 3 H$-pyrazolo[1,5-c][1,3]thiazole in $80 \%$ yield. However, carrying out the 1,3-dipolar cycloaddition of $\mathbf{1 7} \mathbf{c}$ under the same reaction conditions affords $1 \mathrm{H}, 3 \mathrm{H}$ pyrazolo[1,5-c][1,3]thiazole $18 \mathrm{c}$ in only $10 \%$ yield. The yield could be improved to $20 \%$ by reducing the reaction time from $3 \mathrm{~h}$ to $1 \mathrm{~h}$. The oxidation of $1 H, 3 H$-pyrazolo[1,5-c][1,3]thiazoles 18 with MCPBA afforded sulfones 19 in good yield.

The ${ }^{1} \mathrm{H}$ NMR spectra of $N$-nitrosothiazolidine-4-carboxylic acids 16a-16c showed two sets of signals indicating the existence of isomers. Thiazolidine 15a is obtained from $\mathrm{L}_{-}$ cysteine as a $(2 S, 4 R)$ and $(2 R, 4 R)$ diastereoisomeric mixture, but the corresponding $N$-nitroso derivative (16a) can be obtained as a single stereoisomer. In fact, it is known that the acylation of a mixture of $(2 S, 4 R)$ - and $(2 R, 4 R)$-2-substituted-1,3-thiazolidine-4-carboxylates can lead to the selective synthesis of $N$-acyl-2-substituted-1,3-thiazolidine-4-carboxylates as pure stereoisomers with $(2 R, 4 R)$ or $(2 S, 4 R)$ stereochemistry depending on the reaction conditions. 2-Substituted-1,3-thiazolidine-4carboxylates can undergo selective inversion at C-2 through a mechanism involving the opening of the ring, but the protection with the acyl group prevents this epimerization and allows the isolation of pure diastereoisomers. ${ }^{8} \mathrm{~A}$ similar chemical behavior was observed in the one-pot synthesis of the chiral hexahydropyrrolo[1',2',5':3,4,5]thiazolo[3,4-c] oxazol-1-one ring system from $\alpha$-amino acids (L-cysteine and D-penicillamine). ${ }^{9}$ Therefore, the ${ }^{1} \mathrm{H}$ NMR spectrum of $\mathbf{1 6 a}$ could be explained considering the existence of two rotamers. This interpretation is reinforced by the fact that $N$-nitrosothiazolidine-4-carboxylic acid $\mathbf{1 6 b}$, which has only one chiral center, also shows two sets of signals corresponding to two rotamers. Thiazolidine $\mathbf{1 5 c}$ was prepared from DL-penicillamine. Thus, $\mathbf{1 5 c}$ was obtained as a

(8) (a) Szilágyi, L.; Györgydeák, Z. J. Am. Chem. Soc. 1979, 101, 427432. (b) Györgydeák, Z.; Kajtár-Peredy, M.; Kajtár, J.; Kajtár, M. Liebigs Ann. Chem. 1987, 927-934. (c) Benedini, F.; Ferrario, F.; Sala, A.; Sala, L.; Soresinetti, P. A. J. Heterocycl. Chem. 1994, 31, 1343-1347. (d) Fülöp, F.; Mattinen, J.; Pihlaja, K. Tetrahedron 1990, 46, 6545-6552. (e) Lázár, L.; Fülöp, F. Eur. J. Org. Chem. 2003, 3025-3042. (f) Pinho e Melo, T. M. V. D. 1,3-Thiazolidine-4-carboxylic Acids as Building Blocks in Organic Synthesis. In Targets in Heterocyclic Systems-Chemistry and Properties; Attanasi, O. A., Spinelli, D., Eds.; Italian Society of Chemistry: Rome, 2004; Vol. 8, pp 288-329.

(9) Pinho e Melo, T. M. V. D.; Lopes, S. M. M.; Rocha, Gonsalves, A M. d'A.; Kaczor, A. Fausto, R.; Paixão, J. A.; Matos Beja, A.; Ramos Silva, M. Lett. Org. Chem. 2006, 3, 820-826. mixture of $(2 R, 4 R),(2 S, 4 R),(2 S, 4 S)$, and $(2 R, 4 S)$ stereoisomers. However, after the nitrosation reaction $N$-nitrosothiazolidine4-carboxylic acid 16c can be obtained as an enantiomeric mixture. Therefore, again in this case two rotamers would be observed in the ${ }^{1} \mathrm{H}$ NMR spectrum of $\mathbf{1 6 c}$. Evidence of restricted rotation of $\mathrm{N}$-nitroso compounds is well documented, and equilibrium between rotational isomers at room temperature has been encountered for several $\mathrm{N}$-nitrosoamines, including fivemembered cyclic derivatives such as pyrrolidine, thiazolidine, and oxazoline. ${ }^{10}$

The 3-methyl-2,2-dioxo-1H,3H-pyrazolo[1,5-c][1,3]thiazole 19a also undergoes $\mathrm{SO}_{2}$ extrusion in solution to give 20, which can be intercepted in $[8 \pi+2 \pi]$ cycloadditions with electrondeficient dipolarophiles giving the corresponding adducts resulting from the addition across the 1,7-positions in high yields (Table 2). The reaction with DMAD gives a mixture of dihydropyrazolo[1,5- $a$ ]pyridines (21 and 22) in $85 \%$ yield. This mixture can be oxidized with DDQ to give tetramethyl 7-methylpyrazolo[1,5-a]pyridine-2,3,5,6-tetracarboxylate (23) in $40 \%$ yield. The thermolysis of 19a in the presence of methyl propiolate afforded a mixture of regioisomers 4,7-dihydropyrazolo[1,5- $a$ ]pyridine-2,3,6-tricarboxylate $24(30 \%)$ and 4,7-dihydropyrazolo[1,5-a]pyridine-2,3,5-tricarboxylate 25 (38\%).

The 1,7-dipolar cycloaddition of 1,2-diazafulvenium methide 20 with $N$-phenylmaleimide gave two racemic diastereoisomeric products, cycloadducts $\mathbf{2 6}(81 \%)$ and $27(13 \%)$. The structure of the major product (26) was determined by X-ray crystallography (see Supporting Information). The crystal structure showed that the unit cell contains four molecules that are two pairs of enantiomers. The stereochemistry of the enantiomers was established as beeing $(4 \mathrm{a} S, 7 \mathrm{a} S, 8 S)$ and $(4 \mathrm{a} R, 7 \mathrm{a} R, 8 R)$. The formation of cycloadducts $\mathbf{2 6}$ and $\mathbf{2 7}$ can be explained considering a cycloaddition with endo selectivity but with the involvement of the two possible configurations of diazafulvenium methide 20 (see Scheme 7). The lower stability of the configuration having the inward methyl group explains the formation of heterocycle $\mathbf{2 7}$ in a lower yield.

An efficient cycloaddition was observed when sulfone 19a was heated in the presence of $N$-benzylidenebenzenesulfonamide (Table 2). A single cycloadduct $\mathbf{2 8}$ was obtained in $81 \%$ yield. The structure of compound $\mathbf{2 8}$ was unambiguously established on the basis of its ${ }^{1} \mathrm{H}$ NMR spectrum. It shows an ABX system corresponding to $\mathrm{H}-4$ and $\mathrm{H}-5$ protons and a quartet assigned to proton $\mathrm{H}-7$. The cycloaddition of 1,2-diazafulvenium methide 20 with diethyl diazene-1,2-dicarboxylate gave 7-methyl- $4 \mathrm{H}, 7 \mathrm{H}$ pyrazolo[1,5- $d][1,2,4]$ triazine-2,3,5,6-tetracarboxylate $\mathbf{2 9}$ in $79 \%$ yield. In the ${ }^{1} \mathrm{H}$ NMR spectrum of 29 the presence of two conformational isomers could be clearly identified, whereas in the case of derivative $\mathbf{1 4}$, unsubstituted at C-7, the six-membered ring protons are observed as broad signals.

It is noteworthy that the thermolysis of 3-methyl-2,2-dioxo$1 H, 3 H$-pyrazolo[1,5-c][1,3]thiazole 19a in the presence of electron-deficient dipolarophiles requires shorter reaction time than the thermolysis of 2,2-dioxo- $1 H, 3 H$-pyrazolo[1,5-c][1,3]thiazole 3 (Tables 1 and 2). However, an attempt to react 19a

(10) (a) Anet, F. A. L.; Muchowski, J. M. Chem. Ind. 1963, 81-82. (b) Jeyaraman, R.; Senthilkumar, U. P. J. Org. Chem. 1995, 60, 7461-7470. (c) Polonski, T.; Milewska, M. J.; Katrusiak, A. J. Am. Chem. Soc. 1993 , 115, 11410-11417. (d) Roohi, H.; Deyhimi, F.; Ebrahimi, A. J. Mol. Struct. (Theochem) 2001, 543, 299-308. (e) Wu, H.; Loeppky, N.; Glaser, R. J. Org. Chem. 2005, 70, 6790-6801. (f) Haky, J. E.; Saavedra, J. E.; Hilton, B. D. Org. Magn. Reson. 1983, 21, 79-82. (g) Luinsky, W.; Keefer, L.; Loo, J. Tetrahedron 1970, 26, 5137-5153. 
TABLE 2. Solution Pyrolysis of 3-Methyl-2,2-dioxo-1H,3H-pyrazolo[1,5-c][1,3]thiazole 19a in the Presence of Dipolarophiles
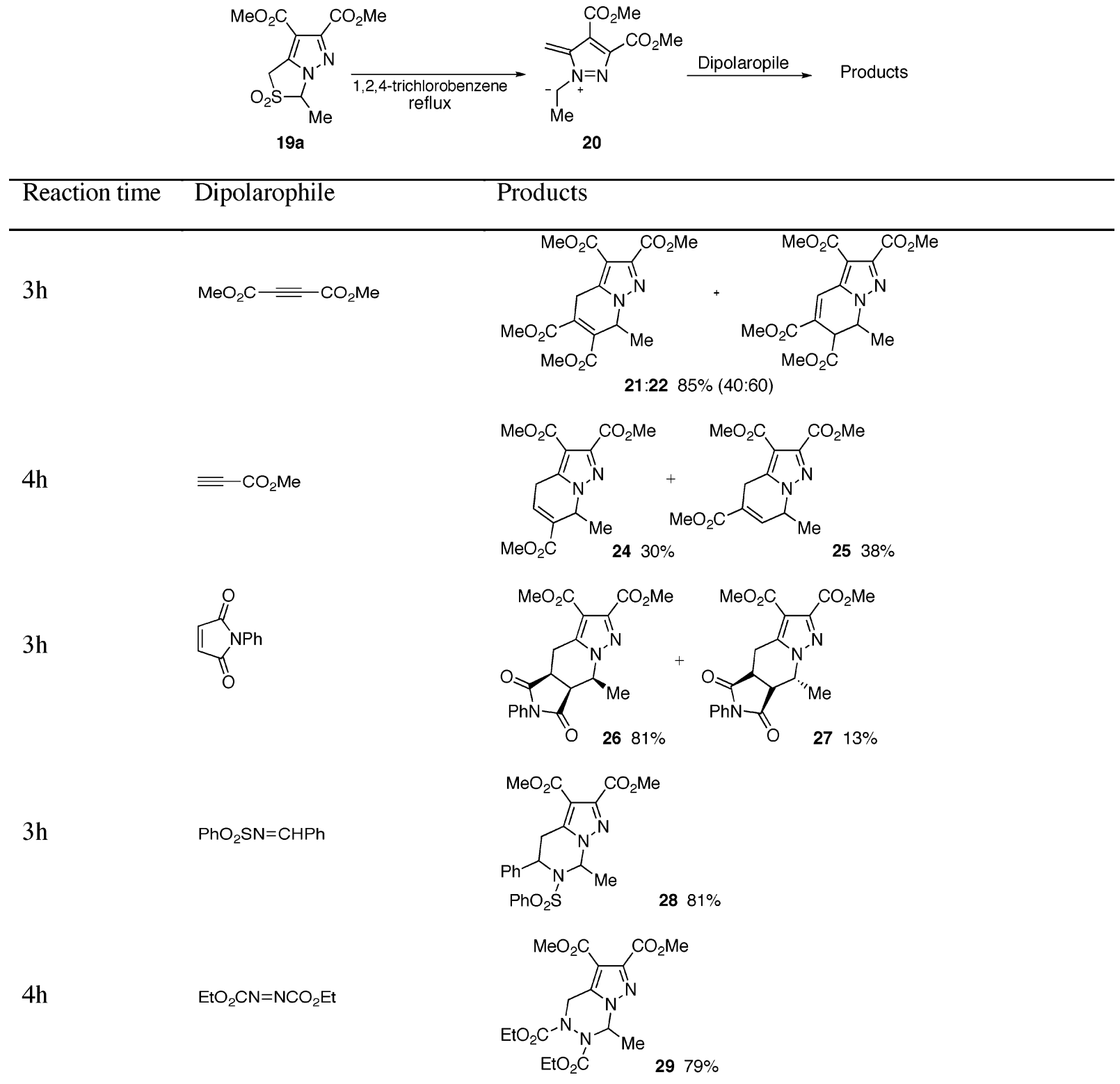

with bis(trimethylsilyl)acetylene led only to the synthesis of the corresponding 1-vinyl- $1 H$-pyrazole 30 in $16 \%$ yield (see Scheme 4).

As previously mentioned the experimentally observed reactivity of 1,7 -dipole 4 toward $[8 \pi+2 \pi]$ cycloaddition is characterized by the participation in the reaction with both electron-rich and electron-deficient dipolarophiles. This is in agreement with the reported semiempirical molecular orbital calculations. ${ }^{5}$ The HOMO and LUMO energies were calculated for 1,2-diazafulvenium methide $4(\mathrm{HO}=-8.5 \mathrm{eV}$ and $\mathrm{LU}=-1.9 \mathrm{eV})$, allowing prediction that the addition to electron-deficient dipolarophiles should be dipole-HOMO controlled while the addition to electron-rich dipolarophiles should be dipole-LUMO controlled. The 1,2-diazafulvenium methide $\mathbf{2 0}$ has an extra methyl group at C-1 leading to an increase of the HOMO and LUMO energies. Therefore, cycloaddition of $\mathbf{2 0}$ with electrondeficient dipolarophiles should be easier than with dipole 4 but the process should be less favorable with electron-rich dipo- larophiles. This was confirmed experimentally, and in fact dipole 20 does not even react with electron-rich dipolarophiles.

Calculations predict a larger atomic orbital coefficient on C-1 than on $\mathrm{C}-7$ in the HOMO of 1,2-diazafulvenium methide 4.5 On the other hand, MNDO and CNDO/2 calculations show a larger atomic orbital coefficient on $\mathrm{C}-3$ than on $\mathrm{C}-2$ in the LUMO of methyl propiolate. ${ }^{11}$ One would therefore expect the selective synthesis of trimethyl 4,7-dihydropyrazolo[1,5-a]pyridine-2,3,5-tricarboxylate $\mathbf{1 1}$ from the reaction of dipole $\mathbf{4}$ with methyl propiolate (Table 1). The experimental result confirmed that regioisomer $\mathbf{1 1}$ is the major product, although it is obtained with low selectivity. The same regioselectivity was observed in the reaction of diazafulvenium methide $\mathbf{2 0}$ with methyl propiolate (Table 2). In contrast with this result, only one regioisomer was obtained from the $[8 \pi+2 \pi]$ cycloaddition of dipoles $\mathbf{4}$ and 20 with $N$-benzylidenebenzenesulfonamide

(11) Dieter, R. K.; Balke, W. H.; Fishpaugh, J. R. Tetrahedron 1988, 44, 1915-1924. 


\section{SCHEME 4}

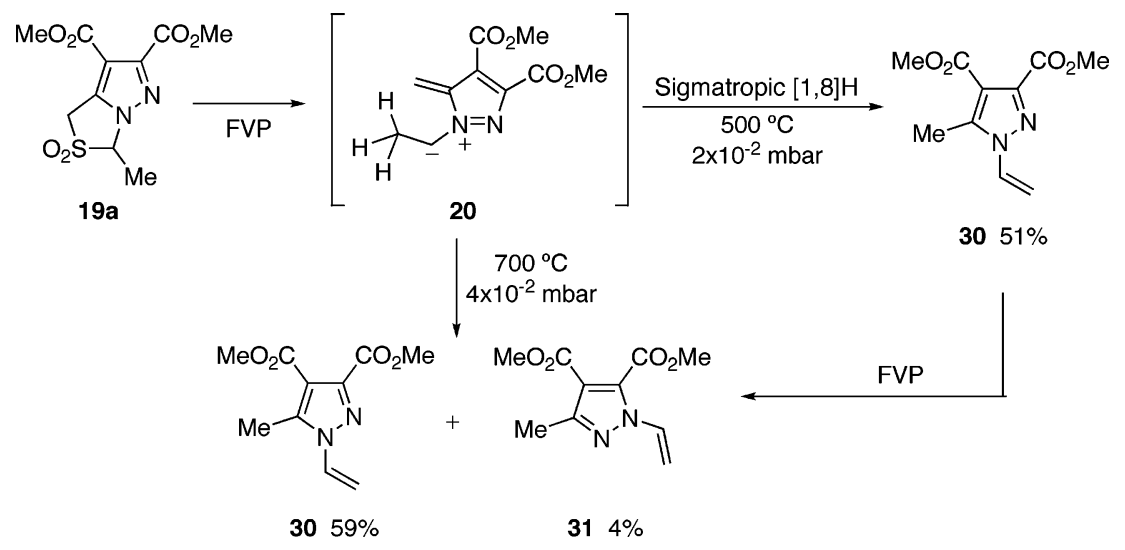

\section{SCHEME 5}

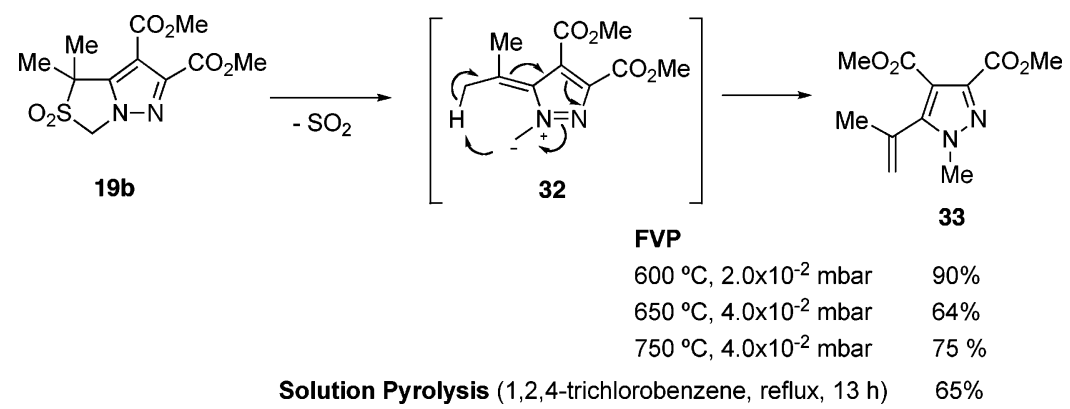

\section{SCHEME 6}

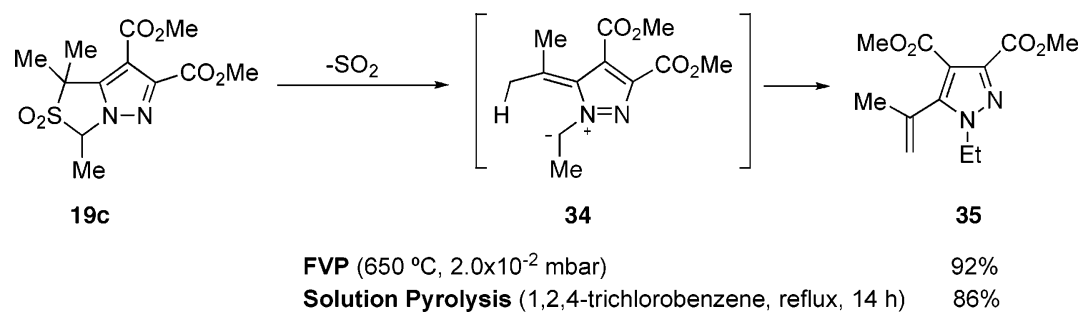

(Tables 1 and 2). A similar regioselectivity pattern is observed in the 1,3-dipolar cycloaddition of mesoionic $N$-methyl-1,3oxazolium-5-olates, dipoles that give only one regioisomer from the reaction with $N$-benzylidenebenzenesulfonamide but lead to a ca. 1:1 mixture of regioisomers on reacting with ethyl propiolate. $^{12}$

The generation and reactivity of diazafulvenium methide systems in the absence of dipolarophiles were studied. By carrying out flash vacuum pyrolysis (FVP) of sulfone 19a at $500{ }^{\circ} \mathrm{C}, 1$-vinyl- $1 \mathrm{H}$-pyrazole $\mathbf{3 0}$ was obtained selectively via the diazafulvenium methide $\mathbf{2 0}$, which was trapped in an intramolecular sigmatropic $[1,8] \mathrm{H}$ shift. When the FVP was carried out at $700{ }^{\circ} \mathrm{C}$, the same 1 -vinyl- $1 H$-pyrazole $\mathbf{3 0}$ was obtained, together with 2-vinyl-2H-pyrazole 31. Pyrazole $\mathbf{3 1}$ is formed by thermal rearrangement of 1-vinyl- $1 H$-pyrazole $\mathbf{3 0}$ since the FVP of this compound leads to a mixture of $\mathbf{3 0}$ and 31 (Scheme 4).

The thermolysis of pyrazole $\mathbf{1 9 b}$ bearing two methyl groups at C-1 was also studied. Under FVP reaction conditions compound 19b affords $C$-vinylpyrazole 33. The optimized conditions $\left(600{ }^{\circ} \mathrm{C}, 2.0 \times 10^{-2} \mathrm{mbar}\right)$ allowed the synthesis of

(12) Bonati, L.; Ferraccioli, R.; Moro, G. J. Phys. Org. Chem. 1995, 8, $452-462$. heterocycle $\mathbf{3 3}$ in $90 \%$ yield (Scheme 5). Attempts to promote a rearrangement of $\mathbf{3 3}$ under FVP led only to sublimation of the pyrazole. On the other hand, the solution pyrolysis of sulfone 19b in the presence of electron-deficient dipolarophiles $(N$ phenylmaleimide or DMAD) or bis(trimethylsilyl)acetylene also gave $C$-vinylpyrazole 33 in yields ranging from $40 \%$ to $50 \%$, and no $[8 \pi+2 \pi]$ cycloadducts were detected. This result can be explained considering the ease with which diazafulvenium methide 32 undergoes sigmatropic $[1,8] \mathrm{H}$ shift, although steric effects can also play an important role making the cycloaddition less favorable. In the absence of dipolorophiles, the optimized solution pyrolysis of sulfone 19b (reflux in 1,2,4-trichlorobenzene for $13 \mathrm{~h}$ ) gave $C$-vinylpyrazole $\mathbf{3 3}$ in $65 \%$ yield.

Flash vacuum pyrolysis 1,1,3-trimethyl-2,2-dioxo- $1 \mathrm{H}, 3 \mathrm{H}$ pyrazolo $[1,5-c][1,3]$ thiazole 19c also leads to the corresponding $C$-vinylpyrazole 35 in high yield (Scheme 6). In this particular case, the $\mathrm{SO}_{2}$ extrusion leads to diazafulvenium methide $\mathbf{3 4}$ where two potential $[1,8] \mathrm{H}$ sigmatropic shifts could in principle occur. However, the FVP of 19c did not afford $N$-vinylpyrazole, giving instead $C$-vinylpyrazole $\mathbf{3 5}$ exclusively. The same type of selectivity was previously observed for sigmatropic $[1,8] \mathrm{H}$ shifts of azafulvenium methides generated from 1,1,3-trimethyl2,2-dioxo- $1 H, 3 H$-pyrrolo[1,2-c][1,3]thiazoles. ${ }^{2}$ The solution pyrolysis of 19c in the presence of $N$-phenylmaleimide gave 


\section{SCHEME 7}

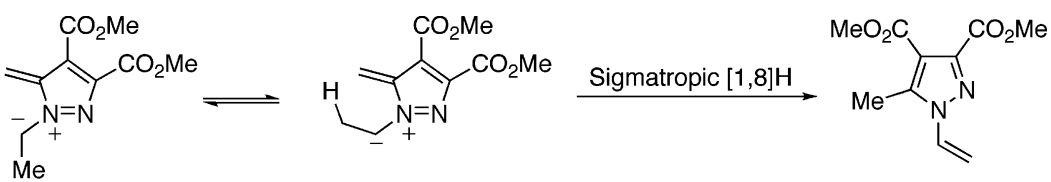

20

30
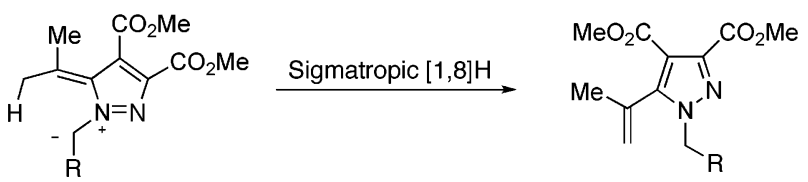

$32 \mathrm{R}=\mathrm{H}$

$\mathrm{R}=\mathrm{H}$

$34 \mathrm{R}=\mathrm{Me}$

$35 \mathrm{R}=\mathrm{Me}$

\section{SCHEME 8}

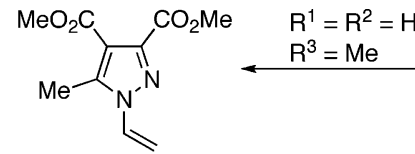

Sigmatropic $[1,8] \mathrm{H}$ Shift<smiles>C=C(C)c1c(C(=O)O)nn(C[18O])c1C(=O)O</smiles>

$\mathrm{R}^{1}=\mathrm{R}^{2}=\mathrm{Me}$

$\mathrm{R}^{3}=\mathrm{H}$ or $\mathrm{Me}$

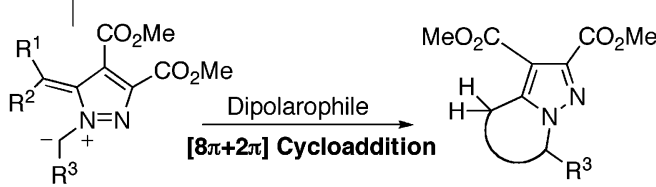

$\mathrm{R}^{1}=\mathrm{R}^{2}=\mathrm{H}$

$\mathrm{R}^{3}=\mathrm{H}$ or $\mathrm{Me}$
$C$-vinylpyrazole $\mathbf{3 5}$ as the only product. By heating at reflux a solution of sulfone 19c in 1,2,4-trichlorobenzene for $14 \mathrm{~h}$, $C$-vinylpyrazole 35 could be obtained in high yield (86\%).

The difference in reactivity observed between diazafulvenium methide $\mathbf{2 0}$ and diazafulvenium methides $\mathbf{3 2}$ and $\mathbf{3 4}$ may reflect the different ease with which the dipoles can attain the configuration required for the sigmatropic shift. In fact, the 7,7dimethyl-diazafulvenium methides (32 and 34) always have a methyl group in the correct position, whereas in the case of diazafulvenium methide $\mathbf{2 0}$ only the configuration having the inward methyl group undergoes the pericyclic reaction (Scheme 7).

The reactivity pattern of the studied diazafulvenium methides is shown in Scheme 8. Thus, diazafulvenium methides unsubstituted at C-7 generated from the solution pyrolysis of 2,2dioxo- $1 H, 3 H$-pyrazolo[1,5-c][1,3]thiazoles participate in $[8 \pi+$ $2 \pi$ ] cycloadditions, giving pyrazolo[ $[1,5-a]$ pyridine derivatives. The diazafulvenium methide derivatives bearing methyl groups at C-1 or C-7 undergo intramolecular sigmatropic $[1,8] \mathrm{H}$ shifts, giving vinyl- $1 H$-pyrazoles.

\section{Conclusions}

We described new chemistry of diazafulvenium methides, generated by the thermal extrusion of sulfur dioxide from 2,2dioxo- $1 H, 3 H$-pyrazolo[1,5-c][1,3]thiazoles.

The diazafulvenium methides unsubstituted at C-7 can be intercepted in $[8 \pi+2 \pi]$ cycloadditions giving pyrazolo[1,5a]pyridine derivatives resulting from the addition across the 1,7position. A range of pyrazolo-annulated heterocycles was obtained, namely, pyrazolo[1,5-a]pyridines, hexahydro- $5 \mathrm{H}$ pyrrolo[3', $\left.4^{\prime}: 5,6\right]$ pyrazolo[1,5- $\left.a\right]$ pyridines, tetrahydropyrazolo- $[1,5-c]$ pyrimidines, and tetrahydropyrazolo $[1,5-d][1,2,4]$ triazines, some of which have potential biological activity. ${ }^{13}$

In the absence of dipolarophiles, 1-methyl-diazafulvenium methide and 7,7-dimethyl-diazafulvenium methides undergo intramolecular sigmatropic $[1,8] \mathrm{H}$ shifts giving $\mathrm{N}$-vinyl- $1 \mathrm{H}$ pyrazoles and $C$-vinyl-1 $H$-pyrazoles, respectively.

Therefore, it has been demonstrated that diazafulvenium methides are valuable intermediates for the synthesis of functionalized pyrazoles.

\section{Experimental Section}

General Procedure for $[8+2]$ Cycloadditions. A suspension of the appropriate 2,2-dioxo- $1 H, 3 H$-pyrazolo[1,5-c][1,3]thiazole6,7-dicarboxylate $(0.87 \mathrm{mmol})$ and dipolarophile $(1.74 \mathrm{mmol})$ in 1,2,4-trichlorobenzene $(2.5 \mathrm{~mL})$ was heated at reflux under dry nitrogen (for $6-7 \mathrm{~h}$, starting from 3 ; for $3-4 \mathrm{~h}$ starting from 19a) for 6-11 h. After cooling to room temperature, the mixture was purified by flash chromatography [hexane] to remove 1,2,4trichlorobenzene followed by elution with ethyl acetate-hexane.

Dimethyl 5,6-Bis(trimethylsilyl)-4,7-dihydro-pyrazolo[1,5-a]pyridine-2,3-dicarboxylate ${ }^{3,5} 5$ and Dimethyl 5,6-Bis(trimethylsilyl)-pyrazolo[1,5-a]pyridine-2,3-dicarboxylate ${ }^{3,5} 6$. The reaction of $\mathbf{3}$ with bis(trimethylsilyl)acetylene gave a mixture, which was purified by flash chromatography [hexane, ethyl acetatehexane (1:4), then ethyl acetate-hexane (1:2)] to give 5 as a solid $(54 \%)$ and 6 as an oil (7\%). Data for 5: $\mathrm{mp} 86.1-87.9{ }^{\circ} \mathrm{C}$ (from ethyl ether-hexane) (compound previously described as a yellowish oil $\left.{ }^{5 b}\right) .{ }^{1} \mathrm{H}$ NMR 0.28 (9H, s), $0.30(9 \mathrm{H}, \mathrm{s}), 3.78$ (2H, approximately

(13) (a) Allen, S. H.; Johns, B. A.; Gudmundsson, K. S.; Freeman, G. A.; Boyd, F. L., Jr.; Sexton, C. J.; Selleseth, D. W.; Creech, K. L.; Moniri, K. R. Biorg. Med. Chem. 2006, 14, 944-954. (b) Elgemeie, G. H.; Zaghary, W. A.; Amin, K. M.; Nasr, T. M. Nucleosodes, Nucleotides, Nucleic Acids 2005, 24, 1227-1247. (c) Jones, P.; Atack, J. R.; Braun, M. P.; Cato, B. P.; Chambers, M. S.; O'Connor, D.; Cook. S. M.; Hobbs, S. C.; Maxey, R.; Szekeres, H. J.; Szeto, N.; Wafford, K. A.; MacLeod, A. M. Bioorg. Med. Chem. Lett. 2006, 16, 872-875. 
$\mathrm{t}, J=4.7 \mathrm{~Hz}), 3.86(3 \mathrm{H}, \mathrm{s}), 3.95(3 \mathrm{H}, \mathrm{s}), 4.76(2 \mathrm{H}$, approximately $\mathrm{t}, J=4.7 \mathrm{~Hz}$ ); MS (EI) $\mathrm{m} / \mathrm{z} 380\left(\mathrm{M}^{+}, 11 \%\right), 365(30), 348$ (48), 275 (100), 73 (36). Data for 6: ${ }^{1} \mathrm{H}$ NMR $0.42(9 \mathrm{H}, \mathrm{s}), 0.44(9 \mathrm{H}$, s), $3.94(3 \mathrm{H}, \mathrm{s}), 4.03(3 \mathrm{H}, \mathrm{s}), 8.45(1 \mathrm{H}, \mathrm{d}, J=0.8 \mathrm{~Hz}), 8.58(1 \mathrm{H}$, $\mathrm{d}, J=0.8 \mathrm{~Hz})$; MS (EI) $\mathrm{m} / \mathrm{z}, 378\left(\mathrm{M}^{+}, 100 \%\right), 363$ (18), 347 (43), 331 (75), 259 (34), 73 (24).

Tetramethyl Pyrazolo[1,5-a]pyridine-2,3,5,6-tetracarboxylate 7, Tetramethyl 4,7-Dihydro-pyrazolo[1,5-a]pyridine-2,3,5,6-tetracarboxylate 8, and Tetramethyl 6,7-Dihydro-pyrazolo[1,5-a]pyridine-2,3,5,6-tetracarboxylate 9 . The reaction of 3 with DMAD gave a mixture, which was purified by flash chromatography [hexane, ethyl acetate-hexane (1:2), then ethyl acetate-hexane (1: $1)$ ] to give in order of elution 7 as a yellow solid (10\%) and a mixture of 8 and $\mathbf{9}$ as a white solid (ratio 28:72) (45\%). Data for 7: $\mathrm{mp}$ 94.7-96.8 ${ }^{\circ} \mathrm{C}$ (from diethyl ether-hexane). IR (KBr) 1730, 1578, 1428, 1328, $1245 \mathrm{~cm}^{-1}$; ${ }^{1} \mathrm{H}$ NMR $3.96(3 \mathrm{H}, \mathrm{s}), 3.97(3 \mathrm{H}, \mathrm{s})$, $3.98(3 \mathrm{H}, \mathrm{s}), 4.05(3 \mathrm{H}, \mathrm{s}), 8.40(1 \mathrm{H}, \mathrm{s}), 9.01(1 \mathrm{H}, \mathrm{s}) ;{ }^{13} \mathrm{C} \mathrm{NMR}$ 52.1, 53.2, 53.3, 105.4, 118.5, 120.2, 131.7, 132.0, 140.7, 149.6, 161.6, 162.3, 163.9, 166.1; MS (EI) $m / z, 350$ ( $\mathrm{M}^{+}, 63 \%$ ), 319 (100), 229 (7), 201 (7); HRMS (EI) $\mathrm{m} / z 350.0757\left(\mathrm{C}_{15} \mathrm{H}_{14} \mathrm{~N}_{2} \mathrm{O}_{8}\left[\mathrm{M}^{+}\right]\right.$, 350.0750). Data for 8 and 9: $\mathrm{mp} 71.9-73.3{ }^{\circ} \mathrm{C}$ (from diethyl ether). IR (KBr) 1738, 1721, 1486, 1433, 1256, $1215 \mathrm{~cm}^{-1} ;{ }^{1} \mathrm{H}$ NMR (minor isomer 8) $3.88(3 \mathrm{H}, \mathrm{s}), 3.90(3 \mathrm{H}, \mathrm{s}), 3.91(3 \mathrm{H}, \mathrm{s})$, $3.99(3 \mathrm{H}, \mathrm{s}), 4.71(2 \mathrm{H}, \mathrm{s}), 5.26(2 \mathrm{H}, \mathrm{s})$; (major isomer 9) $3.69(3 \mathrm{H}$, s), $3.90(3 \mathrm{H}, \mathrm{s}), 3.91(3 \mathrm{H}, \mathrm{s}), 3.96(3 \mathrm{H}, \mathrm{s}), 4.19(1 \mathrm{H}, \mathrm{dd}, J=1.3$ and $6.7 \mathrm{~Hz}), 4.30(1 \mathrm{H}, \mathrm{dd}, J=6.7$ and $13.8 \mathrm{~Hz}), 5.04(1 \mathrm{H}, \mathrm{dd}$, $J=1.3$ and $13.8 \mathrm{~Hz}), 7.93(1 \mathrm{H}, \mathrm{s})$; MS (EI) $\mathrm{m} / \mathrm{z}, 352\left(\mathrm{M}^{+}, 11 \%\right)$, 321 (15), 307 (12), 293 (30), 261 (100), 203 (8). Anal. Calcd for $\mathrm{C}_{15} \mathrm{H}_{16} \mathrm{~N}_{2} \mathrm{O}_{8}$ : C, 51.14; H, 4.58; N, 7.95. Found: C, 51.12; H, 4.99; N, 7.63 .

Trimethyl 4,7-Dihydropyrazolo[1,5-a]pyridine-2,3,6-tricarboxylate 10 and Trimethyl 4,7-Dihydropyrazolo[1,5- $a$ ]pyridine2,3,5-tricarboxylate 11 . The reaction of $\mathbf{3}$ with methyl propiolate gave a mixture, which was purified by flash chromatography [hexane, then ethyl acetate-hexane (1:2)] to give $\mathbf{1 0}(28 \%)$ and $11(33 \%)$ as white solids. Data for10: $\mathrm{mp} 119.5-121.0^{\circ} \mathrm{C}$ (from ethyl acetate-hexane). IR (KBr) 1744, 1697, 1431, 1293, 1251, 1220, $1087 \mathrm{~cm}^{-1}$; ${ }^{1} \mathrm{H}$ NMR $3.86(3 \mathrm{H}, \mathrm{s}), 3.86(3 \mathrm{H}, \mathrm{s}), 3.90(1 \mathrm{H}$, $\mathrm{dd}, J=5.5$ and $3.9 \mathrm{~Hz}), 3.92(1 \mathrm{H}$, dd, $J=5.5$ and $3.8 \mathrm{~Hz}), 3.97$ $(3 \mathrm{H}, \mathrm{s}), 4.95(1 \mathrm{H}, \mathrm{dd}, J=5.6$ and $2.1 \mathrm{~Hz}), 4.97(1 \mathrm{H}, \mathrm{dd}, J=5.6$ and $2.0 \mathrm{~Hz}), 7.22-7.24(1 \mathrm{H}, \mathrm{m}) ;{ }^{13} \mathrm{C}$ NMR $25.6,46.8,51.7,52.4$, 52.6, 110.1, 124.5, 132.5, 140.2, 144.2, 162.3, 162.5, 164.3. HRMS (CI) $\mathrm{m} / \mathrm{z}, 295.0930\left(\mathrm{C}_{13} \mathrm{H}_{15} \mathrm{~N}_{2} \mathrm{O}_{6}\left[\mathrm{M}-\mathrm{H}^{+}\right], 295.0930\right)$. Data for 11: $\mathrm{mp} 141.1-142.5{ }^{\circ} \mathrm{C}$ (from ethyl acetate-hexane). ${ }^{1} \mathrm{H}$ NMR $3.86(3 \mathrm{H}, \mathrm{s}), 3.88(3 \mathrm{H}, \mathrm{s}), 3.94(1 \mathrm{H}, \mathrm{dd}, J=5.6$ and $1.8 \mathrm{~Hz}), 3.96$ $(1 \mathrm{H}, \mathrm{m}), 3.96(3 \mathrm{H}, \mathrm{s}), 4.95(1 \mathrm{H}, \mathrm{dd}, J=5.6$ and $3.4 \mathrm{~Hz}), 4.97$ $(1 \mathrm{H}, \mathrm{dd}, J=5.6$ and $3.4 \mathrm{~Hz}), 7.13-7.16(1 \mathrm{H}, \mathrm{m}) ;{ }^{13} \mathrm{C}$ NMR 24.5 , $47.8,51.8,52.4,52.6,110.6,125.5,129.9,141.3,144.3,162.3$, 162.5, 165.2. HRMS (CI) $m / z, 295.0929\left(\mathrm{C}_{13} \mathrm{H}_{15} \mathrm{~N}_{2} \mathrm{O}_{6}\left[\mathrm{M}-\mathrm{H}^{+}\right]\right.$, 295.0930).

Dimethyl 6-Phenyl-5,7-dioxo-4a,5,6,7,7a,8-hexahydro-5H-pyrrolo $\left[3^{\prime}, 4^{\prime}: 5,6\right]$ pyrazolo[1,5-a]pyridine-2,3-dicarboxylate 12 . The reaction of 3 with $N$-phenylmaleimide required longer reaction time (11 h), giving a product that was purified by flash chromatography [hexane, ethyl acetate-hexane (2:1), then ethyl acetate-hexane (4: 1)] to give $\mathbf{1 2}$ as a white solid (98\%): $\mathrm{mp} 144.8-146.7^{\circ} \mathrm{C}$ (from diethyl ether). IR (KBr) 1715, 1497, 1385, 1221, $1150 \mathrm{~cm}^{-1} ;{ }^{1} \mathrm{H}$ NMR $3.20(1 \mathrm{H}, \mathrm{dd}, J=7.2$ and $16.4 \mathrm{~Hz}), 3.58-3.70(2 \mathrm{H}, \mathrm{m})$, $3.85(3 \mathrm{H}, \mathrm{s}), 3.93(3 \mathrm{H}, \mathrm{s}), 3.93-4.00(1 \mathrm{H}, \mathrm{m}), 4.31(1 \mathrm{H}, \mathrm{dd}, J=$ 5.7 and $13.9 \mathrm{~Hz}), 4.90(1 \mathrm{H}, \mathrm{dd}, J=2.5$ and $13.9 \mathrm{~Hz}), 7.07-7.10$ (2H, m), 7.37-7.44 (3H, m); ${ }^{13} \mathrm{C}$ NMR 22.5, 37.1, 40.4, 46.1, 51.9, 52.6, 112.0, 126.1, 129.0, 129.2, 131.0, 141.5, 143.3, 162.0, 174.9, 176.0; MS (EI) m/z 383 (M+, 28\%), 351 (100), 204 (61), 176 (12), 147 (7), 119 (8), 77 (7). Anal. Calcd for $\mathrm{C}_{19} \mathrm{H}_{17} \mathrm{~N}_{3} \mathrm{O}_{6}$ : C, 59.53; H, 4.47; N, 10.96. Found: C, 59.49; H, 4.64; N, 10.84 .

Dimethyl 5-Phenyl-6-(phenylsulfonyl)-4,5,6,7-tetrahydropyrazolo[1,5-c]pyrimidine-2,3-dicarboxylate 13. The reaction of 3 with $N$-benzylidenebenzenesulfonamide ${ }^{7}$ gave a product, which was purified by flash chromatography [hexane, ethyl acetate-hexane
(1:4), then ethyl acetate-hexane (1:2)] to give $\mathbf{1 3}$ as a solid (45\%). $\mathrm{mp} 165-170{ }^{\circ} \mathrm{C}$ (from diethyl ether); ${ }^{1} \mathrm{H}$ NMR $3.02(1 \mathrm{H}, \mathrm{dd}, J=$ 7.3 and $18.6 \mathrm{~Hz}), 3.6(1 \mathrm{H}, \mathrm{d}, J=18.6 \mathrm{~Hz}), 3.81(3 \mathrm{H}, \mathrm{s}), 3.95(3 \mathrm{H}$, s), $4.74(1 \mathrm{H}, \mathrm{d}, J=14.3 \mathrm{~Hz}) 5.54(1 \mathrm{H}, \mathrm{d}, J=7.3 \mathrm{~Hz}), 5.96(1 \mathrm{H}$, $\mathrm{d}, J=14.3 \mathrm{~Hz}), 7.16-7.96(10 \mathrm{H}, \mathrm{m})$; MS (EI) $\mathrm{m} / \mathrm{z} 455\left(\mathrm{M}^{+}, 8 \%\right)$, 424 (13), 286 (100), 253 (30), 223 (15), 210 (94), 151 (90), 77 (17). HRMS (EI) $\mathrm{m} / \mathrm{z} 445.1159\left(\mathrm{C}_{22} \mathrm{H}_{21} \mathrm{~N}_{3} \mathrm{O}_{6} \mathrm{~S}\left[\mathrm{M}^{+}\right], 445.1151\right)$.

5,6-Diethyl 2,3-Dimethyl 4,5,6,7-Tetrahydropyrazolo[1,5- $d]$ $[1,2,4]$ triazine-2,3,5,6-tetracarboxylate 14 . The reaction of 3 with diethyl diazene-1,2-dicarboxylate gave a product, which was purified by flash chromatography [hexane, ethyl acetate-hexane (1:4), then ethyl acetate-hexane (1:2)] to give a colorless oil (65\%): IR (KBr) 1733, 1402, 1211, 1090; ${ }^{1} \mathrm{H}$ NMR 1.30-1.34 (6H, m), $3.87(3 \mathrm{H}, \mathrm{s}), 3.97(3 \mathrm{H}, \mathrm{s}) 4.27-4.29(4 \mathrm{H}, \mathrm{m}), 4.7(1 \mathrm{H}, \mathrm{bs})$, $5.40(2 \mathrm{H}, \mathrm{bs}), 6.2(1 \mathrm{H}, \mathrm{bs}) ;{ }^{13} \mathrm{C}$ NMR $14.3,14.5,42.5$ (bs), 52.0, 52.7, 61.4 (bs), 63.4, 64.2, 110.8, 139.3, 143.9, 154.0, 161.8; MS (EI) $\mathrm{m} / z .384\left(\mathrm{M}^{+}, 11 \%\right), 352$ (83), 284 (45), 235 (46), 207 (83), 179 (100), 151 (44). HRMS (EI) $m / z 384.1274\left(\mathrm{C}_{15} \mathrm{H}_{20} \mathrm{~N}_{4} \mathrm{O}_{8}\left[\mathrm{M}^{+}\right]\right.$, $384.1281)$

Tetramethyl 7-Methyl-4,7-dihydro-pyrazolo[1,5-a]pyridine2,3,5,6-tetracarboxylate 21 and Tetramethyl 7-Methyl-6,7dihydro-pyrazolo[1,5- $a$ ]pyridine-2,3,5,6-tetracarboxylate 22 . The reaction of 19a with DMAD (reaction time $3 \mathrm{~h}$ ) gave a mixture, which was purified by flash chromatography [hexane, ethyl acetate-hexane (1:2), then ethyl acetate-hexane (1:1)] to give a mixture of $\mathbf{2 1}$ and $\mathbf{2 2}$ (ratio 40:60) as a yellowish oil (85\%). IR (KBr) 1730, 1433, 1217, $1090 \mathrm{~cm}^{-1}$; ${ }^{1} \mathrm{H}$ NMR (minor isomer 21) $1.40(3 \mathrm{H}, \mathrm{d}, J=6.9 \mathrm{~Hz}), 3.68(3 \mathrm{H}, \mathrm{s}), 3.86(3 \mathrm{H}, \mathrm{s}), 3.90(3 \mathrm{H}, \mathrm{s})$, $3.96(3 \mathrm{H}, \mathrm{s}), 4.05-4.07(1 \mathrm{H}, \mathrm{m}), 4.52-4.56(1 \mathrm{H}, \mathrm{m}), 5.22-5.32$ $(1 \mathrm{H}, \mathrm{m})$; (major isomer 22$) 1.78(3 \mathrm{H}, \mathrm{d}, J=6.8 \mathrm{~Hz}), 3.66(3 \mathrm{H}, \mathrm{s})$, 3.86-3.98 (2H, m), $3.88(3 \mathrm{H}, \mathrm{s}), 3.91(3 \mathrm{H}, \mathrm{s}), 3.96(3 \mathrm{H}, \mathrm{s}), 7.96$ (1H, s); MS (EI) m/z 366 (M $\left.\mathrm{M}^{+}, 9 \%\right), 335$ (14), 307 (48), 275 (100), 261 (19), 59 (9). HRMS (EI) $\mathrm{m} / z, 366.1062\left(\mathrm{C}_{16} \mathrm{H}_{18} \mathrm{~N}_{2} \mathrm{O}_{8}\left[\mathrm{M}^{+}\right]\right.$, 366.1064).

Trimethyl 7-Methyl-4,7-dihydropyrazolo[1,5- $a$ ]pyridine-2,3,6tricarboxylate 24 and Trimethyl 7-Methyl-4,7-dihydropyrazolo$[1,5-a]$ pyridine-2,3,5-tricarboxylate 25 . The reaction of 19a with methyl propiolate gave a mixture, which was purified by flash chromatography [hexane, then ethyl acetate-hexane (1:2)] to give $24(30 \%)$ and $25(38 \%)$. Data for 24: obtained as a colorless oil; ${ }^{1} \mathrm{H}$ NMR $1.63(3 \mathrm{H}, \mathrm{d}, J=6.5 \mathrm{~Hz}), 3.78-4.04(2 \mathrm{H}, \mathrm{m}), 3.86(3 \mathrm{H}$, s), $3.87(3 \mathrm{H}, \mathrm{s}), 3.97(3 \mathrm{H}, \mathrm{s}), 5.31-5.38(1 \mathrm{H}, \mathrm{m}), 7.18-7.21(1 \mathrm{H}$, $\mathrm{m}) ;{ }^{13} \mathrm{C}$ NMR $22.7,25.2,51.7,52.3,52.6,53.6,109.9,130.6,132.4$, 139.8, 144.1, 162.6, 162.7, 164.4; MS (EI) $\mathrm{m} / z 308\left(\mathrm{M}^{+}, 2 \%\right), 277$ (14), 261 (100), 217 (11). HRMS (CI+) $m / z 309.1087\left(\mathrm{C}_{12} \mathrm{H}_{16} \mathrm{~N}_{2} \mathrm{O}_{4}\right.$ $\left.\left[\mathrm{MH}^{+}\right], 309.1087\right)$. Data for 25: obtained as a white solid; $\mathrm{mp}$ 99- $100{ }^{\circ} \mathrm{C}$ (from ethyl acetate-hexane). IR (KBr) 1745, 1721, 1710, 1313, 1270, 1091, $1064 \mathrm{~cm}^{-1} ;{ }^{1} \mathrm{H}$ NMR $1.69(3 \mathrm{H}, \mathrm{d}, J=$ $6.9 \mathrm{~Hz}), 3.84(3 \mathrm{H}, \mathrm{s}), 3.87(3 \mathrm{H}, \mathrm{s}), 3.91(1 \mathrm{H}, \mathrm{dd}, J=5.0$ and 2.1 $\mathrm{Hz}), 3.94(1 \mathrm{H}, \mathrm{dd}, J=5.0$ and $1.6 \mathrm{~Hz}), 3.97(3 \mathrm{H}, \mathrm{s}), 5.07-5.08$ $(1 \mathrm{H}, \mathrm{m}), 7.05(1 \mathrm{H}$, approximately $\mathrm{dt}, J \approx 2.1,1.6$ and $3.6 \mathrm{~Hz}) ;{ }^{13} \mathrm{C}$ NMR 21.6, 24.4, 51.7, 52.4, 52.6, 53.8, 110.2, 124.3, 135.6, 140.8, 144.3, 162.6, 162.7, 165.4; MS (EI) $\mathrm{m} / z 308\left(\mathrm{M}^{+}, 4 \%\right), 277$ (20), 261 (100), 217 (15). HRMS (CI+) $m / z, 309.1083\left(\mathrm{C}_{12} \mathrm{H}_{16} \mathrm{~N}_{2} \mathrm{O}_{4}\right.$ $\left.\left[\mathrm{MH}^{+}\right], 309.1087\right)$.

(4aS,7aS,8S)-Dimethyl 8-Methyl-5,7-dioxo-6-phenyl-4a,5,6,7,7a,8-hexahydro- $1 \mathrm{H}, 3 \mathrm{H}$-pyrazolo $[1,5-a]$ pyrrolo $[3,4-d]$ pyridine2,3-dicarboxylate 26 and $(4 \mathrm{a} S, 7 \mathrm{a} S, 8 R)$-8-Methyl-5,7-dioxo-6phenyl-4a,5,6,7,7a,8-hexahydro- $1 \mathrm{H}, 3 \mathrm{H}$-pyrazolo[1,5-a]pyrrolo[3,4$d$ ]pyridine-2,3-dicarboxylate 27 . The reaction of 19 a with $N$-phenylmaleimide (reaction time $3 \mathrm{~h}$ ) gave a mixture, which was purified by flash chromatography [hexane, ethyl acetate-hexane (2:1), then ethyl acetate] to give in order of elution 27 as an oil $(13 \%)$ and 26 as a white solid (81\%). Data for 26: $\mathrm{mp} 155.6-$ $157.7^{\circ} \mathrm{C}$ (from ethyl acetate-hexane); IR (KBr) $1735,1716,1562$, 1473, 1447, 1383, $1222 \mathrm{~cm}^{-1} ;{ }^{1} \mathrm{H}$ NMR $1.69(3 \mathrm{H}, \mathrm{d}, J=7.0 \mathrm{~Hz})$, $3.53-3.72(4 \mathrm{H}, \mathrm{m}), 3.87(3 \mathrm{H}, \mathrm{s}), 3.95(3 \mathrm{H}, \mathrm{s}), 4.85-4.94(1 \mathrm{H}$, m), 7.15-7.18 (2H, m), 7.41-7.47 (3H, m); ${ }^{13} \mathrm{C}$ NMR 15.4, 21.2, $37.3,44.7,51.9,52.7,53.3,111.9,126.2,129.1,129.3,131.0,141.0$, 
143.4, 162.3, 162.4, 173.3, 176.2; MS (EI) m/z. $397\left(\mathrm{M}^{+}, 15 \%\right)$, 365 (100), 218 (13), 203 (54), 77 (8). Anal. Calcd for $\mathrm{C}_{20} \mathrm{H}_{19} \mathrm{~N}_{3} \mathrm{O}_{6}$ : C, 60.45; H, 4.82; N, 10.57. Found: C, 60.63; $\mathrm{H}$, 4.99; N, 10.43. Data for 27: IR (KBr) 1740, 1715, 1670, 1541, 1491, 1393, $1229 \mathrm{~cm}^{-1} ;{ }^{1} \mathrm{H}$ NMR $1.69(3 \mathrm{H}, \mathrm{d}, J=7.0 \mathrm{~Hz}), 3.37$ $(1 \mathrm{H}, \mathrm{dd}, J=8.2$ and $16.8 \mathrm{~Hz}), 3.42(1 \mathrm{H}, \mathrm{dd}, J=2.9$ and $9.6 \mathrm{~Hz})$, $3.61(1 \mathrm{H}$, ddd, $J=3.1,8.2$ and $9.6 \mathrm{~Hz}), 3.86(3 \mathrm{H}, \mathrm{s}), 3.92(1 \mathrm{H}$, dd, $J=3.1$ and $16.8 \mathrm{~Hz}), 3.94(3 \mathrm{H}, \mathrm{s}), 5.12(1 \mathrm{H}, \mathrm{dq}, J=2.9$ and $7.0 \mathrm{~Hz}), 7.12-7.27(2 \mathrm{H}, \mathrm{m}), 7.38-7.46(3 \mathrm{H}, \mathrm{m}) ;{ }^{13} \mathrm{C}$ NMR 20.5 , 22.0, 36.4, 46.2, 52.0, 52.6, 53.9, 112.2, 126.1, 129.0, 129.2, 131.0, 140.2, 143.4, 162.1, 162.2, 174.8, 176.2; MS (EI) $\mathrm{m} / z 397\left(\mathrm{M}^{+}\right.$, 24\%), 365 (100), 217 (10), 203 (59), 183 (8). HRMS (EI) $\mathrm{m} / z$ $397.1279\left(\mathrm{C}_{20} \mathrm{H}_{19} \mathrm{~N}_{3} \mathrm{O}_{6}\left[\mathrm{M}^{+}\right], 397.1274\right)$.

Dimethyl 7-Methyl-5-phenyl-6-(phenylsulfonyl)-4,5,6,7-tetrahydropyrazolo[1,5-c]pyrimidine-2,3-dicarboxylate 28 . The reaction of 19a with $N$-benzylidenebenzenesulfonamide ${ }^{7}$ (reaction time $3 \mathrm{~h}$ ) gave a product, which was purified by flash chromatography [hexane, then ethyl acetate-hexane (2:1)] to give $\mathbf{2 8}$ as a white foam (81\%): IR (KBr) 1745, 1736, 1336, 1216, 1173, 1082 $\mathrm{cm}^{-1} ;{ }^{1} \mathrm{H}$ NMR $1.18(3 \mathrm{H}, \mathrm{d}, J=6.6 \mathrm{~Hz}), 2.91(1 \mathrm{H}, \mathrm{dd}, J=$ 17.8 and $J=7.4 \mathrm{~Hz}), 3.75(1 \mathrm{H}, \mathrm{dd}, J=17.8$ and $J=2.4 \mathrm{~Hz})$, $3.86(3 \mathrm{H}, \mathrm{s}), 3.94(3 \mathrm{H}, \mathrm{s}) 5.57(1 \mathrm{H}, \mathrm{dd}, J=7.4$ and $J=2.4 \mathrm{~Hz})$, $6.31(1 \mathrm{H}, \mathrm{q}, J=6.6 \mathrm{~Hz}), 7.27-7.33(4 \mathrm{H}, \mathrm{m}), 7.49-7.52(4 \mathrm{H}, \mathrm{m})$, 7.80-7.83 (2H, m); ${ }^{13} \mathrm{C}$ NMR 23.1, 24.1, 51.2, 51.8, 52.7, 68.1, $110.2,126.8,127.4,128.4,128.9,129.7,133.6,138.3,139.0,140.4$ 143.8, 162.5. HRMS (EI) $\mathrm{m} / \mathrm{z} 469.1297 \quad\left(\mathrm{C}_{23} \mathrm{H}_{23} \mathrm{~N}_{3} \mathrm{O}_{6} \mathrm{~S}\left[\mathrm{M}^{+}\right]\right.$, 469.1308).

5,6-Diethyl 2,3-Dimethyl 7-methyl-4,5,6,7-tetrahydropyrazolo[1,5- $d][1,2,4]$ triazine-2,3,5,6-tetracarboxylate 29 . The reaction of 19a with diethyl diazene-1,2-dicarboxylate gave 29 as a white solid (79\%): mp $119-119.5{ }^{\circ} \mathrm{C}$ (from diethyl ether); IR (KBr) 1753, 1741, 1721 1376, 1338, 1314, 1289, 1210; ${ }^{1} \mathrm{H}$ NMR (DMSO$d_{6}$ ) (the ${ }^{1} \mathrm{H}$ NMR spectrum showed the existence of two rotamers) (major rotamer) $1.16-1.21(6 \mathrm{H}, \mathrm{m}), 1.60(3 \mathrm{H}, \mathrm{d}, J=6.4 \mathrm{~Hz}), 3.77$ $(3 \mathrm{H}, \mathrm{s}), 3.84(3 \mathrm{H}, \mathrm{s}), 4.10-4.21(4 \mathrm{H}, \mathrm{m}), 4.58(1 \mathrm{H}, \mathrm{d}, J=$ $17.2 \mathrm{~Hz}), 5.27(1 \mathrm{H}, \mathrm{d}, J=17.2 \mathrm{~Hz}), 6.39(1 \mathrm{H}, \mathrm{q}, J=6.4 \mathrm{~Hz}) ;{ }^{13} \mathrm{C}$ NMR (DMSO- $\left.d_{6}\right) 14.1,14.3,19.6,41.8,51.8,52.5,60.6,62.7$, 63.5, 108.8, 138.6, 143.6, 154.3, 161.3, 162.3; MS (EI) m/z 398 $\left(\mathrm{M}^{+}, 4 \%\right), 367$ (16), 284 (100), 253 (19), 221 (19), 193 (50), 180 (144), 116 (42). HRMS (EI) $\mathrm{m} / z .398 .1426\left(\mathrm{C}_{16} \mathrm{H}_{22} \mathrm{~N}_{4} \mathrm{O}_{8}\left[\mathrm{M}^{+}\right]\right.$, $398.1438)$.

General Procedure for Flash Vacuum Pyrolysis. Pyrolysis of the appropriate 2,2-dioxo- $1 H, 3 H$-pyrazolo[1,5-c][1,3]thiazole-6,7dicarboxylate $(1.0 \mathrm{mmol})$ at $500-800{ }^{\circ} \mathrm{C}$ and $2 \times 10^{-2}$ to $4 \times$ $10^{-2}$ mbar onto a surface cooled at $-196^{\circ} \mathrm{C}$ over a period of $1.5-$ $2 \mathrm{~h}$ gave a colorless pyrolysate. [The rate of volatilization of the starting material was controlled by the use of a Kugelrohr oven, which heated the sample at $80-180{ }^{\circ} \mathrm{C}$ ]. After cooling to room temperature the pyrolysate was removed from the cold finger with dichloromethane, and the solvent was removed in vacuo.

Dimethyl 5-Methyl-1-vinyl-1H-pyrazole-3,4-dicarboxylate 30 and Dimethyl 5-Methyl-2-vinyl-2H-pyrazole-3,4-dicarboxylate 31. Pyrolysis of 19a at $700{ }^{\circ} \mathrm{C} / 4 \times 10^{-2}$ mbar gave a mixture, which was purified by flash chromatography [ethyl acetate-hexane (1:2), then ethyl acetate-hexane $(1: 1)$ ] to give in order of elution $\mathbf{3 1}$ as a colorless oil (4\%) and $\mathbf{3 0}$ as a white solid (59\%). Data for 30: $\mathrm{mp} 46.3-48.0^{\circ} \mathrm{C}$ (from diethyl ether-hexane); IR (KBr) 1740 , 1719, 1648, 1320, 1269, $1088 \mathrm{~cm}^{-1} ;{ }^{1} \mathrm{H}$ NMR $2.56(3 \mathrm{H}, \mathrm{s}), 3.85$ $(3 \mathrm{H}, \mathrm{s}), 3.95(3 \mathrm{H}, \mathrm{s}), 5.14(1 \mathrm{H}, \mathrm{dd}, J=0.9$ and $8.8 \mathrm{~Hz}), 5.95(1 \mathrm{H}$, $\mathrm{dd}, J=0.9$ and $15.2 \mathrm{~Hz}), 6.99(1 \mathrm{H}, \mathrm{dd}, J=8.8$ and $15.2 \mathrm{~Hz}) ;{ }^{13} \mathrm{C}$ NMR 10.3, 51.7, 52.5, 106.4, 112.6, 128.2, 142.9, 144.4, 162.8, 163.0; MS (EI) m/z 224 (M+, 28\%), 193 (100), 163 (27), 133 (12), 68 (9). Anal. Calcd for $\mathrm{C}_{10} \mathrm{H}_{12} \mathrm{~N}_{2} \mathrm{O}_{4}$ : C, 53.57; H, 5.39; N, 12.49 . Found: C, 53.75; H, 5.28; N, 12.39. Data for 31: IR (KBr) 1719, 1646, 1545, 1442, 1260, $1109 \mathrm{~cm}^{-1}$; ${ }^{1} \mathrm{H}$ NMR 2.46 (3H, s), 3.84
$(3 \mathrm{H}, \mathrm{s}), 3.96(3 \mathrm{H}, \mathrm{s}), 5.03(1 \mathrm{H}, \mathrm{dd}, J=0.7$ and $8.8 \mathrm{~Hz}), 5.87(1 \mathrm{H}$, $\mathrm{dd}, J=0.7$ and $15.2 \mathrm{~Hz}), 7.19(1 \mathrm{H}, \mathrm{dd}, J=8.8$ and $15.2 \mathrm{~Hz}) ;{ }^{13} \mathrm{C}$ NMR 13.4, 51.8, 53.2, 105.0, 114.1, 129.7, 145.0, 151.0, 160.7, 163.1; MS (EI) m/z $224\left(\mathrm{M}^{+}, 40 \%\right), 192$ (100), 167 (7), 135 (11), 79 (6).

Dimethyl 5-Methyl-1-vinyl-1H-pyrazole-3,4-dicarboxylate 30. Pyrolysis of 19a at $500{ }^{\circ} \mathrm{C} / 2 \times 10^{-2}$ mbar gave a product, which was purified by flash chromatography [ethyl acetate-hexane (1: $2)$, then ethyl acetate-hexane (1:1)] to give $\mathbf{3 0}$ as a white solid $(51 \%)$. Compound 30 was identified by comparison with the specimen previously prepared (see above).

Dimethyl 1-Methyl-5-(prop-1-en-2-yl)-1H-pyrazole-3,4-dicarboxylate 33. Pyrolysis of $19 \mathrm{~b}$ at $600{ }^{\circ} \mathrm{C} / 2 \times 10^{-2}$ gave a product, which was purified by flash chromatography [ethyl acetate-hexane (1:1)] to give 33 as a white foam (90\%): IR (KBr) 1745, 1736, 1475, 1317, 1221, $1074 \mathrm{~cm}^{-1}$; ${ }^{1} \mathrm{H}$ NMR 2.07 (3H, bs), $3.83(3 \mathrm{H}$, s), $3.85(3 \mathrm{H}, \mathrm{s}), 3.91(3 \mathrm{H}, \mathrm{s}), 5.13(1 \mathrm{H}, \mathrm{bs}), 5.54(1 \mathrm{H}, \mathrm{m}) ;{ }^{13} \mathrm{C}$ NMR 22.6, 37.3, 51.9, 52.5, 112.8, 121.2, 133.6, 142.1, 147.4, 162.2, 163.0; MS (EI) m/z, $238\left(\mathrm{M}^{+}, 17 \%\right), 206$ (100), 195 (25), 248 (24), 120 (12). HRMS (EI) $\mathrm{m} / z, 238.0963\left(\mathrm{C}_{11} \mathrm{H}_{14} \mathrm{~N}_{2} \mathrm{O}_{4}\left[\mathrm{M}^{+}\right]\right.$, 238.0954).

Dimethyl 1-Ethyl-5-(prop-1-en-2-yl)-1H-pyrazole-3,4-dicarboxylate 35 . Pyrolysis of $19 \mathrm{c}$ at $650{ }^{\circ} \mathrm{C} / 2 \times 10^{-2}$ gave a product, which was purified by flash chromatography [ethyl acetate-hexane (1:1)] to give as a colorless oil (92\%): IR (film) 1746, 1730, 1480, 1320, 1216, $1083 \mathrm{~cm}^{-1} ;{ }^{1} \mathrm{H}$ NMR $1.44(3 \mathrm{H}, \mathrm{t}, J=7.2 \mathrm{~Hz}), 2.08$ $(3 \mathrm{H}, \mathrm{m}), 3.83(3 \mathrm{H}, \mathrm{s}), 3.94(3 \mathrm{H}, \mathrm{s}), 4.16(2 \mathrm{H}, \mathrm{q}, J=7.2 \mathrm{~Hz}), 5.13$ $(1 \mathrm{H}, \mathrm{m}), 5.53(1 \mathrm{H}, \mathrm{m}) ;{ }^{13} \mathrm{C}$ NMR 15.8, 23.0, 45.1, 51.8, 52.4, 112.5, 120.9, 133.7, 142.4, 146.9, 162.5, 163.0; MS (EI) $\mathrm{m} / z .252\left(\mathrm{M}^{+}\right.$, 21\%), 220 (100), 205 (73), 193 (12), 161 (12). HRMS (EI+) m/z $252.1111\left(\mathrm{C}_{12} \mathrm{H}_{16} \mathrm{~N}_{2} \mathrm{O}_{4}\left[\mathrm{M}^{+}\right], 252.1110\right)$.

General Procedure for Solution Thermolysis. A solution of the appropriate 1,1-dimethyl-2,2-dioxo- $1 H, 3 H$-pyrazolo[1,5-c][1,3]thiazole-6,7-dicarboxylate $(0.30 \mathrm{mmol})$ in 1,2,4-trichlorobenzene $(1.8 \mathrm{~mL})$ was heated at reflux under dry nitrogen for $13-14 \mathrm{~h}$. After cooling to room temperature, the mixture was purified by flash chromatography [hexane] to remove 1,2,4-trichlorobenzene followed by elution with ethyl acetate-hexane to give the products.

Dimethyl 1-Methyl-5-(prop-1-en-2-yl)-1H-pyrazole-3,4-dicarboxylate 33. Compound 33 was obtained from $19 \mathrm{~b}$ in $65 \%$ yield. Pyrazole 33 was purified by flash chromatography [hexane, then ethyl acetate-hexane (1:1)] and was identified by comparison with the specimen previously prepared (see above).

Dimethyl 1-Ethyl-5-(prop-1-en-2-yl)-1H-pyrazole-3,4-dicarboxylate 35. Compound 35 was obtained from 19c in $86 \%$ yield. Pyrazole 35 was purified by flash chromatography [hexane, then ethyl acetate-hexane (1:3)] and was identified by comparison with the specimen previously prepared (see above).

Tetramethyl Pyrazolo[1,5- $a$ ]pyridine-2,3,5,6-tetracarboxylate 7 from 8 and 9. A suspension of the mixture of 4,7-dihydropyrazolo[1,5- $a$ ]pyridine-2,3,5,6-tetracarboxylate 8 and 6,7-dihydropyrazolo[1,5-a]pyridine-2,3,5,6-tetracarboxylate $\quad 9 \quad(0.09 \quad \mathrm{~g}$, $0.26 \mathrm{mmol})$ and DDQ (0.07 $\mathrm{g}, 1.2$ equiv, $0.31 \mathrm{mmol})$ in $1,2,4-$ trichlorobenzene $(5.0 \mathrm{~mL})$ was heated in sealed tube at $260{ }^{\circ} \mathrm{C}$ for $3 \mathrm{~h}$. After cooling to room temperature, the tube was opened, and the mixture filtered through celite. The crude product was purified by flash chromatography [hexane] to remove 1,2,4trichlorobenzene followed by elution with ethyl acetate-hexane $(1: 1)$, then ethyl acetate-hexane $(2: 1)$ to give 7 as a yellow solid (44\%). Compound 7 was identified by comparison with the specimen previously prepared.

Tetramethyl 7-Methylpyrazolo[1,5- $a]$ pyridine-2,3,5,6-tetracarboxylate 23. A suspension of the mixture 7-methyl-4,7-dihydropyrazolo[1,5- $a$ ]pyridine-2,3,5,6-tetracarboxylate 21 and 7-methyl6,7-dihydro-pyrazolo[1,5-a]pyridine-2,3,5,6-tetracarboxylate $\mathbf{2 2}$ $(0.04 \mathrm{~g}, 0.12 \mathrm{mmol})$ and DDQ $(0.03 \mathrm{~g}, 1.2$ equiv., $0.14 \mathrm{mmol})$ in 1,2,4-trichlorobenzene $(2.0 \mathrm{~mL})$ was heated in sealed tube at $260{ }^{\circ} \mathrm{C}$ for $3 \mathrm{~h}$. After cooling to room temperature, the tube was 
opened and the mixture was filtered through celite. The crude product was purified by flash chromatography [hexane] to remove 1,2,4-trichlorobenzene followed by elution with ethyl acetatehexane (1:2), then ethyl acetate-hexane (1:1) to give $\mathbf{2 3}(40 \%)$ as a yellow solid: $\mathrm{mp} 110.5-111.3{ }^{\circ} \mathrm{C}$ (from ethyl ether-hexane); IR (KBr) 1744, 1714, 1304, 1272, 1210, $1120 \mathrm{~cm}^{-1}$; ${ }^{1} \mathrm{H}$ NMR 2.85 $(3 \mathrm{H}, \mathrm{s}), 3.97(6 \mathrm{H}, \mathrm{s}), 3.99(3 \mathrm{H}, \mathrm{s}), 4.05(3 \mathrm{H}, \mathrm{s}), 8.68(1 \mathrm{H}, \mathrm{s}) ;{ }^{13} \mathrm{C}$ NMR 15.3, 52.1, 53.1, 53.2, 53.3, 105.5, 119.7, 120.1, 130.0, 138.9, 139.8, 148.5, 162.0, 163.1, 164.6, 166.6; MS (EI) m/z $364\left(\mathrm{M}^{+}\right.$, $70 \%), 333$ (100), 301 (14), 274 (29), 246 (16), 59 (11). Anal. Calcd for $\mathrm{C}_{16} \mathrm{H}_{16} \mathrm{~N}_{2} \mathrm{O}_{8}$ : C, 52.75; H, 4.43; N, 7.69. Found: C, 52.79; H, $4.66 ; \mathrm{N}, 7.68$.
Acknowledgment. We thank Chymiotechnon, Fundação para a Ciência e a Tecnologia (POCI/QUI/55584/2004 and SFRH/BD/9123/2002) and FEDER for financial support.

Supporting Information Available: Experimental procedures and characterization data for compounds $16 \mathbf{a}-16 \mathbf{c}, 17 \mathbf{a}-17 \mathbf{c}, 18 \mathbf{a}-$ 18c, and 19a-19c. NMR spectra for all new compounds. Crystallographic data for dimethyl 8-methyl-5,7-dioxo-6-phenyl-4a,5,6,7,7a,8-hexahydro- $1 H, 3 H$-pyrazolo[ $1,5-a]$ pyrrolo[3,4- $d$ ]pyridine-2,3dicarboxylate 26 in CIF format. This material is available free of charge via the Internet at http://pubs.acs.org.

JO070265X 